\title{
Stress Levels and High School Adolescents Coping Mechanism during the Covid-19 Pandemic
}

\author{
Mustika Sajida Maharani ${ }^{\star 1} \odot$; Mustikasari Mustikasari²® \\ ${ }^{1 *}$ Faculty of Nursing, Universitas Indonesia, Depok, Indonesia \\ ${ }^{2}$ Departement of Psychiatric Nursing, Faculty of Nursing, Universitas Indonesia, \\ Depok, Indonesia
}

\begin{abstract}
Background: Adolescents are prone to psychological disorders due to their personal nature that they cannot accept changes. It is further exacerbated by the Covid-19 pandemic situation which requires all activities to be carried out online from home.

Purpose: This study aims to determine the relationship between stress levels and coping mechanism in high school adolescents during the Covid-19 pandemic in Halim Jakarta.

Methods: Research design is a cross sectional used for adolescents aged 15-19 years at SMA Negeri 67 Jakarta and SMA Angkasa 1. 342 samples were selected by using the quota sampling method. The measurement of stress levels is done by distributing the Perceived Stress Scale (PSS) questionnaire, while the coping mechanism uses the Brief Cope questionnaire. The research results include the results of univariate analysis and bivariate analysis with the Chi Square test.

Results: The results of this study showed that there was a relationship between stress levels and coping mechanism ( $p$ value 0.017 ), dysfunctional coping strategies ( $p$ value 0.000 ) in high school adolescents during the Covid-19 pandemic. Furthermore, there is no relationship between stress levels and Emotion Focused Strategies ( $p$ value 0.703), and Problem Focused Strategies ( $p$ value 0.816 ) in high school adolescents during the Covid-19 pandemic. The female adolescents are more dominant than male adolescents. More respondents from class XII majoring in science are from SMA Negeri 67 Jakarta. There are still teenagers with severe stress during the Covid-19 pandemic. There is a relationhip between stress levels with coping mechanism and dysfunctional coping strategies. But the stress level has no relationship with Emotion Focused Strategies and Problem Focused Strategies.

Conclusion: The results of this study are expected to improve mental health services through routine mental health screening and providing counselling related to stress management in adolescents. Adolescents are also expected to solve problems by optimizing the use of coping mechanism (Emotion Focused Strategies, Problem Focused Strategies) appropriately and avoiding the use of dysfunctional coping strategies.
\end{abstract}

Gopen access

\section{Jurnal Keperawatan Padjadjaran (JKP)}

Volume 9(3), 240-246 (C) The Author(s) 2021 https://doi.org/10.24198/jkp. v9i3.1678

\section{Article Info \\ Received : July 22, 2021 \\ Revised : November 26, 2021 \\ Accepted : November 29, 2021 \\ Published : December 29, 2021 \\ Corresponding author}

Mustika Sajida Maharani

Faculty of Nursing, Universitas

Indonesia, Depok, Indonesia,

Postal address: 16425, Phone: 62 87887042028, E-mail: mustika.

sajida@ui.ac.id

Citation

Maharani, M.S., \& Mustikasari, M. (2021). Stress Level and High School Adolescents Coping Mechanisn during the Covid-19 Pandemic. Jurnal Keperawatan Padjadjaran, 9(3), 240-246. https://doi.org/10.24198/jkp. v9i3.1678

\section{Website}

http://jkp.fkep.unpad.ac.id/index. php/jkp

This is an Open Access article distributed under the terms of the Creative Commons Attribution-NonCommercial 4.0 International License.

E-ISSN: 2442-7276

P-ISSN: 2338-5324
Keywords: adolescents; coping mechanism; covid-19; stress.

\section{Introduction}

The Corona virus has been declared a pandemic by the WHO (World Health Organization) since March 9, 2020, and this virus has spread widely to all parts of the world (WHO, 2020). This virus is new and this disease was not known before the outbreak in Wuhan, China, in December 2019. The Covid-19 pandemic also caused psychosocial problems. Based on the research conducted, the prevalence of stress was $29.6 \%$. The anxiety level was $31.9 \%$ and depression was $33.7 \%$ (Salari et al., 2020). Based on the data above, stress is one of the health issues that should not be ignored.

Adolescence is a period of transition from childhood to adulthood 
Original Article

Maharani, M.S., et al. (2021)

Table 1. Average Distribution of High School Respondents During the Covid-19 Pandemic at Halim Jakarta Based on Adolescent Age at Halim in 2021 ( $N=342$ )

\begin{tabular}{lccccc}
\hline Characteristics of Respondents & $\begin{array}{c}\text { Mean } \\
\text { Median } \\
\text { Mode }\end{array}$ & SD & Min-Max & Cl 95\% \\
\hline Age & 16.40 & 0.906 & $15-19$ & $16.30-16.50$ \\
& 16 & & & \\
\hline
\end{tabular}

Table 2. Frequency Distribution of Respondents Based on Gender, Class, Major, and School Origin of High School Teenagers During the Covid-19 Pandemic at Halim Jakarta Based on Adolescent Age at Halim 2021 ( $N=342)$.

\begin{tabular}{lcc}
\hline \multicolumn{1}{c}{ Characteristics of Respondents } & Total & Percentage (\%) \\
\hline Gender & & 34.2 \\
Boy & 117 & 65.8 \\
Girl & 225 & \\
Class & & 26.9 \\
X & 92 & 30.4 \\
XI & 104 & 42.7 \\
XII & 146 & \\
Major & & 36.5 \\
IPA & 217 & 63.5 \\
IPS & 125 & \\
School Origin & & 59.1 \\
SMAN 67 Jakarta & 202 & 40.9 \\
SMA Angkasa 1 & 140 & \\
\hline
\end{tabular}

Table 3. Distribution of Frequency Based on Stress Levels of High School Adolescents during the Covid-19 Pandemic in Halim Jakarta by Adolescent Age in Halim 2021 (N=342).

\begin{tabular}{lcc}
\hline \multicolumn{1}{c}{ Variable } & Total & Percentage (\%) \\
\hline Stress Level & & \\
Mild & 20 & 5.8 \\
Moderate & 216 & 63.2 \\
Severe & 106 & 31 \\
Total & 342 & 100 \\
\hline
\end{tabular}

Table 4. Distribution of Average Respondents by Level of High School Adolescent Coping Mechanisms during the Covid-19 Pandemic in Halim Jakarta by Adolescent Age in Halim 2021 (N=342).

\begin{tabular}{llcc}
\hline \multicolumn{1}{c}{ Variable } & & Total & Percentage (\%) \\
\hline Coping Mechanism & Less & 36 & 10.5 \\
Emotion Focused Strategies & Good & 306 & 89.5 \\
& Less & 200 & 58.5 \\
Problem Focused Strategies & Good & 142 & 41.5 \\
& Less & 201 & 58.8 \\
Dysfunctional Coping Strategies & Good & 141 & 41.2 \\
& Less & 297 & 86.8 \\
& Good & 45 & 13.2 \\
\hline
\end{tabular}


Stress Levels and High School Adolescents

Table 5. The Relationship Between Stress Levels and Coping Mechanisms for High School Adolescent during the Covid-19 Pandemic in Halim Jakarta based on Adolescent Age in Halim 2021 $(\mathrm{N}=342)$.
(Hockenberry \& Wilson, 2015). Adolescents are vulnerable to psychological disorders because they have not been able to accept changes easily. Some of the changes caused by Covid-19 have an impact on all aspects such as the start of online classes, not being able to meet and play with friends, the routine of parents working from home. These changes can make teenagers become stressed (Ananda \& Apsari, 2020). Adolescents also experience several things that cause stress including changes in learning methods. At first they learned face-to-face, but with conditions like this, the learning turned into distance learning (Ananda \& Apsari, 2020). Based on a survey conducted by KPAI (Indonesian Child Protection Commission), as many as $79.9 \%$ of children experienced increased stress due to lack of interaction with the teacher and the teacher only gave heavy tasks, and $20.1 \%$ still thought that there was interaction in the learning process. The stress experienced by teenagers during the Covid-19 pandemic is classified as academic stress (Muslim, 2020). One of the causes of adolescent stress levels during the Covid-19 pandemic is because studying at home is difficult and the online learning system is becoming less effective.

Based on the researcher's preliminary study of 10 high school teenagers in Jakarta, it showed that during the Covid-19 pandemic, teenagers felt stressed due to the Distance Learning method. To deal with stress, teenagers do several things such as playing games, chatting with friends using social media, and exercising. The way that teenagers do to relieve stress is by implementing commonly used coping.

The results of the research conducted on high school students on the use of coping mechanism showed that $55.2 \%$ of respondents used adaptive coping mechanism and $44.8 \%$ of respondents used maladaptive coping mechanism. The maladaptive coping mechanism that has been used are consuming alcohol, smoking, fighting, and playing games. The adaptive coping mechanism used by adolescents, for example talking to other people, trying to solve existing problems, and also relaxation techniques (Mulyana, 2013). Diverting thoughts and doing other activities are some examples of ways to reduce stress. Reducing stress levels in online learning will also result in decreased coping mechanism (Fitriasari, Septianingrum, Budury, \& Khamida, 2020). Based on this, the purpose of this study was to determine the relationship between stress levels and the coping mechanism of high school adolescents during the Covid-19 pandemic in Halim Jakarta.

\section{Methods}

The design of this research is a cross sectional (Notoatmodjo, 2010). The sample criteria are students between the ages of 15-19 years, and willing to become research respondents. Respondent selected by quota sampling with a sample of 342 
respondents held on January 16-22 2021 in SMA Negeri 67 and SMA Angkasa 1 Halim Jakarta Timur. The questionnaire used: 1) the characteristics of the respondents, namely age, gender, school origin, major, and class made by the researcher himself, 2) the stress level (Perceived Stress Scale from Cohen (Cohen, 1983) consisting of 10 questions, and 3 ) the coping mechanism (Brief COPE from Carver (1997)) consisting of 28 questions. This questionnaire was originally in English, then the researcher translated this questionnaire into Indonesian with the help from a sworn translator. Data were collected through online media (Google Form). The analysis in this study used univariate analysis and bivariate analysis with chi-square test. This research has passed the ethics test Faculty of Nursing, Universitas Indonesia with Nomor: SK-03/UN2.F12.D1.2.1/ETHIC 2021.

\section{Results}

The results of this study include 1) respondent characteristics including age, gender, school origin, major, and class, 2) stress level, and 3) coping mechanism.

\section{Characteristics of respondents}

Next are the characteristics of other respondents as in table 1.

The average age obtained is 16.40 years, with the youngest age of 15 years and the oldest age of 19 years.

Table 2 shows the number of female respondents consisting of 225 adolescents. The number of respondents in class XII consists of 146 teenagers. The number of teenagers from the science department consists of 217 teenagers. The number of teenagers from SMA Negeri 67 Jakarta consists of 202 teenagers.

\section{Stress Level}

Table 3 shows that there are still teenagers who are under severe stress, with $31 \%$.

\section{Coping Mechanism}

Table 4 shows that adolescents are good at using coping mechanisms (89.5\%), emotion focused strategies (41.5\%), and problem focused strategies $(41.2 \%)$. Only $13.2 \%$ of teenagers are not good at using Dysfunctional Coping Strategies.

\section{Coping Mechanism}

Table 5 shows that there is a relationship between stress levels and coping mechanisms ( $p$ value $=$ 0.017), Dysfunctional Coping Strategies ( $p$ value $=0.000)$ for high school adolescents during the Covid-19 pandemic. There is no relationship between stress levels and Emotion Focused Strategies ( $p$ value $=0.703)$, Problem Focused Strategies $(p$ value $=0.816$ ) for high school adolescents during the Covid-19 pandemic.

\section{Discussion}

\section{Characteristics of respondents}

Characteristics of the respondents consist of age, gender, school origin, major, and class. The age of the respondents is the average age of 16.4 years old. The respondent's age ranges from 15-19 years. Based on $\mathrm{WHO}$, this age range is included in the category of middle (14-16 years old) and late teens (16-19 years old). Adolescence is a transition from childhood to adulthood. Adolescents have unstable emotions causing them to be unable to solve the problems they are facing, adolescents also do not have mature thoughts about the future (Rahmawati, Rohaedi, \& Sumartini, 2019). Skills in dealing with stressors and the use of coping mechanisms are related to a person's age (Fitriasari et al., 2020). A person's ability to manage stress is accompanied by the development of the age (Suwartika, Nurdin, \& Ruhmadi, 2014). Teenagers still have difficulty on accepting reality so they are easier to experience stress because they are not used to changes.

Female adolescent respondents are more dominant than boys. This is supported by the research that adolescent girls are more susceptible to stress than adolescent boys. This is because boys are easier to feel confident, independent, and able to become leaders, while girls are more emotionally oriented (Sharma \& Kaur, 2011). Teenage girls are more prone to experiencing high levels of stress because girls experience puberty earlier than boys (Budiarti, 2013). The results of the study are in accordance with (Dapodikbud, 2020) which shows that there are more female students than male students. The respondents from science major are more dominant than social studies respondents. This is comparable to research conducted by Wulandari (2014) which obtained data that adolescents from the science department were more dominant than the social studies major. There is a significant difference in the level of anxiety between the science majors and the social studies majors (Krisnawati, 2011). The results of the study also stated that although there was a perception that the science department gave higher pressure than the social studies major, there was actually no significant difference in the level of stress between the two majors (Allred, Granger, \& Hogstrom, 2013). The level of stress experienced by adolescents from the science department is caused by pressure to follow all lessons and difficulties in understanding lessons.

The majority of the respondents are from class $\mathrm{XII}$, followed by class $\mathrm{XI}$, and lastly is class X. According to a study, the characteristics of class XI students are able to adapt to the school environment and learning activities well and have plenty of time for self-exploration (Setiono, 2013). The majorities of class XI students already have good selfunderstanding, have a good sense of enthusiasm for learning, and have good relationships with their friends (Lestari, Sofah, \& Putri, 2019). According 
to a study, class XII students have a higher risk of experiencing psychosocial problems because the higher a person's education level causes the stress received from the burden of learning to increase also (Putri, 2014). The researcher assumes that the stress level experienced by teenagers is highest in class XII due to the high burden of learning to continue to college level.

The results showed that the majority of adolescent respondents came from SMA Negeri 67 Jakarta rather than from SMA Angkasa 1 Jakarta (Dapodikbud, 2020). This result is in accordance with the data held by Dapodikbud which shows that the number of students attending SMA Negeri 67 Jakarta is more than students attending SMA Angkasa 1 Jakarta. Public schools are schools run by the government, while private schools are usually run by a foundation. For the number of students, there are usually more students from public schools than students from private schools because the capacity of public schools is bigger than the capacity of private schools.

\section{Stress Level}

The data from the results of this study indicate that there are still teenagers who belong to the category of severe stress. Adolescents also experience several things that cause stress, including changes in learning methods. At first they learn with face-toface learning, but this current condition has made the learning process turn into distance learning (Ananda \& Apsari, 2020). Teenagers experience increased stress due to social restrictions that cause teens not to be able to spend time playing with their friends (Houston, 2020). The average teenagers experience moderate levels of stress during the pandemic due to difficulties on understanding online material and fears of being infected (Purba, 2020). Severe stress lasts several weeks to years, this stress begins to affect a person's mental and physical. The causes of stress experienced by adolescents include academic, individual relationships, peer problems, and life changes (Apriningtyas Budiyati \& Oktavianto, 2020). Some of the difficulties experienced by adolescents are caused by the additional cost of the internet and a lack of understanding of technology (Purwanto et al., 2020). The level of stress experienced by adolescents can be caused by several things, including teenagers who have not been able to accept changes, some of the changes experienced by adolescents include changes in the way of learning to distance learning.

\section{Coping Mechanism}

The results of the study found that adolescents were able to use coping mechanisms but there were still some adolescents who had not been able to use coping mechanisms optimally. More than $50 \%$ of teenagers still use the Dysfunctional Coping Strategies mechanism. Teenagers are more dominant in using coping mechanisms of Emotionfocused strategy. The use of Dysfunctional Coping
Strategies is caused by the severity of a stressor experienced. To overcome this, guidance and counselling services are needed for adolescents to tell about their feelings during learning and can use the focus group discussion method (Sary, 2011). The usual coping mechanism for adolescents is adaptive coping mechanisms, but there are some adolescents who use maladaptive coping mechanisms.

Effective problem solving requires the use of both functions of coping mechanisms to deal with the stress (Fitriasari et al., 2020). Most people use adaptive coping mechanisms such as watching television or watching movies, cleaning and tidying things up, keeping in touch with friends and family during a pandemic (Taylor et al., 2020). Teenagers are more likely to use problem-focused coping mechanisms to deal with stress (Raheel, 2014). Adolescents have begun to be able to determine the appropriate coping mechanisms to deal with the stressors they experience.

The coping mechanisms they use are very diverse. Adolescents usually use problem-focused coping mechanisms. Problem-focused coping is a strategy by making a change and taking action to deal with a situation. Emotion-focused coping focuses on actions to reduce emotional distress, commonly known as a defense mechanism, an attempt to eliminate feelings of anxiety (Lazarus \& Folkman, 1984; Stuart, 2013). Dysfunctional coping strategies refer more to maladaptive coping and do not resolve the stress. Based on the researcher's analysis, the coping mechanism needs to be improved, namely the use of Problem-focused strategies and Emotionfocused strategies. Teenagers begin to find out about coping mechanisms from several online media sources, and reference sources. The use of dysfunctional coping strategies is not recommended because it tends to not solve the problem because the coping used is maladaptive.

\section{The Relationship between Stress Level and Coping Mechanism}

Based on the results of the study, there are still teenagers experiencing severe stress who have not used coping mechanisms optimally and use Dysfunctional Coping Strategies coping mechanisms. The results showed that there was a relation between stress levels with coping mechanisms and dysfunctional coping strategies. Stress level has no relationship with Emotion Focused Strategies and Problem Focused Strategies.

The results of this study are in accordance with the research and the data shows that respondents with high levels of stress have tried various coping mechanisms, including adaptive coping mechanisms such as using the internet to keep in touch with others through text messages, and creating routines (Taylor et al., 2020). Some ways to reduce stress are by doing other activities or sleeping. The decrease in stress levels in online learning will also be followed by the decrease in coping mechanisms 
(Fitriasari et al., 2020).

The level of stress experienced by adolescents can be overcome if adolescents maximize the use of coping mechanisms. The use of coping mechanisms must be appropriate because there are coping mechanisms that do not cope with the stress experienced.

\section{Conclusion}

The characteristics of the respondents are mostly in the middle age category, with female adolescents more dominant than male adolescents. More respondents from class XII majoring in science are from SMANegeri 67 Jakarta. There are still teenagers with severe stress during the Covid-19 pandemic. The number is not too large but it needs attention. Teenagers are able to use coping mechanism (Emotion Focused Strategies, Problem Focused Strategies) well but still not optimal and there are still some teenagers who use Dysfunctional Coping Strategies. There is a relationhip between stress levels with coping mechanism and dysfunctional coping strategies. However, the stress level has no relationship with Emotion Focused Strategies and Problem Focused Strategies. Adolescents are also able to use coping mechanism optimally but there are still some teenagers who have not maximized the use of coping mechanism.

It is hoped that through this research, the government will make regulations that emphasize policies on the community to care about mental health, especially the mental health of children and adolescents as well as creating guidebooks and optimizing the maximum use of coping mechanism (Emotion Focused Strategies, Problem Focused Strategies) in overcoming stress during the pandemic and avoiding the use of Dysfunctional Coping Strategies through the creation of educational content in social media. The government can also create a complaint post in each region to receive complaints from teenagers related to stress problems they experience and provide lessons related to optimizing coping mechanism.

Schools can conduct health promotions regarding stress management and optimize the use of coping mechanism for Problem Focused Strategies and Emotion Focused Strategies optimally during the pandemic through online seminars, and health promotion related to stress levels and use coping mechanism for Problem Focused Strategies and Emotion Focused Strategies optimally by using social media.

Nurses can provide health promotion in the form of counselling related to the selection of coping mechanism and stress management as well as conducting counselling related to the adolescent development process that can affect stress levels and how to optimize the use of pandemic coping mechanism (Emotion Focused Strategies, Problem Focused Strategies) and avoiding the use of Dysfunctional Coping Strategies which can be done by providing education to students as much as possible. Nurse can also educate the adolescents that these coping mechanisms are not recommended and help adolescents choose other coping mechanism such as by trying to share their thoughts. Nurses can also provide guidance and counselling to adolescents in accordance with the development of age who experience severe stress.

Teachers are expected to be a place for teenagers to share their thought and help the students during distance learning, so that teenagers who are experiencing stress can be given counselling and assistance. Teenagers begin to find out what activities they like to deal with stress. It is hoped that teenagers can also do stress management so that they can reduce stress levels.

The Researchers hope that the results of this study can be used for the development of nursing science, especially psychiatric nursing and can provide information about interventions related to stress levels experienced by adolescents during the Covid-19 pandemic and the selection of the use of appropriate coping mechanism and also maximizing the use of coping mechanism (Problem Focused Strategies dan Emotion Focused Strategies).

\section{References}

Allred, A., Granger, M., \& Hogstrom, T. (2013, February 12). The Relationship Between Academic Major, Personality Type, and Stress In College Students. Retrieved January 22, 2021, from https://www.lakeforest.edu/ news/the-relationship-between-academicmajor-personality-type-and-stress-in-collegestudents

Ananda, S. S. D, \& Apsari, N. N. (2020). Mengatasi Stress Pada Remaja Saat Pandemi Covid-19. Prosiding Penelitian \& Pengabdian Kepada Masyarakat, 7(2), 248-256. https://doi. org/10.24198/jppm.v7i2.29050

Budiyati, G, A., \& Oktavianto, E. (2020). Stres Dan Resiliensi Remaja Di Masa Pandemi Covid-19. Husada Mahakam: Jurnal Kesehatan, 10(2), 11-18. https://doi.org/10.35963/hmjk. v10i2.227

Budiarti, A. N. (2013, ). Hubungan asupan zat gizi mikro dan faktor lainnya dengan nilai stres pada remaja di SMA Negeri 68 Jakarta Pusat tahun 2013. [Bachelor's Thesis, University of Indonesia]. Universitas Indonesia Library. Retrieved December 12, 2020, from https://lib. ui.ac.id/detail id $=20346768$ \&lokasi=lokal

Carver C. S. (1997). You want to measure coping but your protocol's too long: consider the brief COPE. International journal of behavioral medicine, 4(1), 92-100. https://doi. org/10.1207/s15

Cohen, S., Kamarck, T., \& Mermelstein, R. (1983). A global measure of perceived stress. Journal of Health and Social Behavior, 24(4), 385-396. https://doi.org/10.2307/2136404 
Dapodikbud. (2020, February 4). Sekolah Kita. Retrieved February 4, 2021, from http:// sekolah.data.kemdikbud.go.id/

Houston, F. (2020, October 9). Too young to be stressed: Adolescent mental health in the COVID-19 pandemic. Retrieved February 21, 2021, from https://www.uchicagomedicine. org/forefront/news/too-young-to-be-stressedout-ingalls-behavioral-health-focuses-onadolescents-too

Fitriasari, A., Septianingrum, Y., Budury, S., \& Khamida, K. (2020). Stress pembelajaran online berhubungan dengan strategi koping mahasiswa selama pandemi covid-19. Jurnal Keperawatan. Nursing Journal, 12(4), 985992. https://doi.org/10.32583/keperawatan. v12i4.1047

Hockenberry, M. J., \& Wilson, D. (2015). Wong's nursing care of infants and children 10th ed. Elsevier.

Krisnawati, O. O. (2011). Perbedaan Tingkat Kecemasan Siswa Kelas XI Antara Jurusan IPA dan IPS di SMA Negeri 1 Babadan Ponorogo. . [Bachelor's Thesis, Universitas Muhammadiyah Surakarta]. UMS Library. Retrieved February 12, 2021, from http:// eprints.ums.ac.id/14854/

Lazarus, R., \& Folkman, S. (1984). Stress, appraisal, and coping. Springer Publishing Company.

Lestari, D. P., Sofah, R., \& Putri, R. M. (2019). Tingkat kecerdasan emosi peserta didik kelas XI di SMA Negeri 15 Palembang. Jurnal Konseling Komprehensif: Kajian Teori Dan Praktik Bimbingan Dan Konseling, 6(1), 11-20. https://doi.org/10.36706/jkk.v6i1.8498

Mulyana. (2013). Gambaran mekanisme koping remaja di SMAN 30 Jakarta. [Bachelor's Thesis, University of Indonesia]. Universitas Indonesia Library. Retrieved February 21, 2021, from https://lib.ui.ac.id/abstrakpdf. jspdetail?id=20348475\&lokasi=lokal

Muslim, M. (2020). Manajemen stress pada masa pandemi COVID-19 ". Jurnal Manajemen Bisnis, 23(2), 192-201. https://doi. org/10.55886/esensi.v23i2.205

Notoatmodjo, S. (2010). Metodologi Penelitian Kesehatan. Rineka Cipta.

Purba, S. A. B. (2020). Tingkat stres pada siswa yang bersekolah dengan media daring di Madrasah Aliyah Negeri 2 Model Medan. [Bachelor's Thesis, Universitas Sumatera Utara]. USU Repository. Retrieved February 28, from https://repositori.usu.ac.id/bitstream/ handle/123456789/29092/161101111. pdf? sequence $=1$ \&isAllowed $=y$

Purwanto, A., Pramono, R., Asbari, M., Santoso, P. B., Wijayanti, L. M., Choi, C. H., \& Putri, R. S. (2020). Studi eksploratif dampak pandemi COVID-19 terhadap proses pembelajaran online di Sekolah Dasar. EduPsyCouns: Journal of Education, Psychology and Counseling, 2(1), 1-12. https://ummaspul.e-
journal.id/Edupsycouns/article/view/397

Putri, W. D. A. W. (2014). Prevalensi Stres Psikososial Dan Faktor - Faktor Yang Mempengaruhi Pada Siswa - Siswi Kelas XII Studi Pendidikan Ipa Dan Ips Sman 6 Denpasar. Stres Psikososial, (Prevalence of Psychosocial Stress and Factors Affecting Students in Class XII Science and Social Studies Education at Sman 6 Denpasar. E-Jurnal Medika Udayana, 3(11), $1-12$.

Raheel H. (2014). Coping strategies for stress used by adolescent girls in Riyadh, Kingdom of Saudi Arabia. Pakistan journal of medical sciences, 30(5), 958-962. https://doi.org/10.12669/ pjms.305.5014

Rahmawati, M. N., Rohaedi, S., \& Sumartini, S. (2019). Tingkat stres dan indikator stres pada remaja yang melakukan pernikahan dini. Jurnal Pendidikan Keperawatan Indonesia, 5(1), 25-33. https://doi.org/10.17509/jpki. v5i1.11180

Salari, N., Hosseinian-Far, A., Jalali, R., VaisiRaygani, A., Rasoulpoor, S., Mohammadi, M., Khaledi-Paveh, B. (2020). Prevalence of stress, anxiety, depression among the general population during the COVID-19 pandemic: A systematic review and meta-analysis. Globalization and Health, 16(1). https://doi. org/10.1186/s12992-020-00589-w

Sary, Y. K. (2011). Perilaku Maladaptif Dalam Proses Pembelajaran Siswa Kelas Viii Sekolah Menengah Pertama Negeri 23 Pekanbaru. [Bachelor's Thesis, State Islamic University of Sultasn Syarif Kasim]. Institutional Repository. Retrieved February 21, 2021, from https:// repository.uin-suska.ac.id/433/

Setiono, S. E. (2013). Hubungan antara religiusitas dengan kenakalan remaja pada siswa-siswi kelas XI SMK Negeri 2 Malang. [Bachelor's Thesis, Universitas Islam Negeri Maulana Malik Ibrahim]. Universitas Islam Negeri Maulana Malik Ibrahim. Retrieved February 21, 2021 from http://etheses.uin-malang. ac.id/1722/

Sharma, M., \& Kaur, G. (2011). Gender differences in Proscatination and Academic Stress among adolescents. Indian Journal Of Social Science Resourches, 8(1-2), 122-127. Retrieved February 21, 2021 from https://www.yumpu. com/en/document/read/30272531/genderdifferences-in-procrastination-and-academicstress-among-

Suwartika, I., Nurdin, A., \& Ruhmadi, E. (2014). Analisis Faktor Yang Berhubungan Dengan Tingkat Stress Akademik Mahasiswa Reguler Program Studi D III Keperawatan Cirebon Poltekkes Kemenkes Tasikmalaya. The Soedirman Journal of Nursing), 9(3), 173-189. Retrieved from http://jks.fikes.unsoed.ac.id/ index.php/jks/article/viewFile/612/337

Taylor, S., Landry, C. A., Paluszek, M. M., Fergus, T. A., McKay, D., \& Asmundson, G. J. G. 
Original Article

Maharani, M.S., et al. (2021)

(2020). Development and initial validation of the COVID Stress Scales. Journal of Anxiety Disorders, $\quad 72 . \quad$ https://doi.org/10.1016/j. janxdis.2020.102232

WHO. (2020). Coronavirus disease (COVID-19) outbreak: Rights, roles and responsibilities of health workers, including key considerations for occupational safety. World Health Organization.
Wulandari, R. (2014). Gambaran tingkat stres akademik pada remaja di SMA Negeri 1 Depok. [Bachelor's Thesis, University of Indonesia]. Universitas Indonesia Library. Retrieved February 21, 2021, from https://lib.ui.ac.id/ detail.jsp?id=20388118\#: : :text=Hasil\%20 penelitian $\% 20$ didapatkan $\% 20$ data $\% 20$ 51.6 ,mengenai $\% 20$ stress $\% 20$ akademik $\% 20$ pada $\% 20$ remaja. 